\title{
ANALYSIS OF CHANGES IN LAND SURFACE TEMPERATURE IN THE OIL AND GAS MINING INDUSTRY SECTOR IN BOJONEGORO REGENCY
}

\author{
Mrabawani Insan Rendra ${ }^{1}$, Anindya Putri Tamara ${ }^{1}$ \\ ${ }^{1}$ Magister Perencanaan Wilayah dan Kota, Universitas Diponegoro, Indonesia \\ Email Korespondensi: m.insanrendra@gmail.com
}

DOI: $10.31314 /$ jsig.v3i2.661

Abstract - This study aims at determining changes in the surface temperature of the mining and oil and gas mining industry. The method that used was the analysis using the 1997 Land 5 Tm Image and the 2018 Oil Landsat 8 Image and seeing the growth in the GRDP of Bojonegoro Regency. The results of this study show: The surface temperature in Bojonegoro Regency in 1997 an average of 20-30 ${ }^{\circ} \mathrm{C}$ and 30-35 ${ }^{\circ} C$ was in the eastern part of Bojonegoro Regency, namely part of Kanor District, part of Baoureno District, part of Kepohbaru District, part of Sumberejo District, part of Kepohbaru District and part of Sokosewu District. However, there was an increase in soil surface temperature in 2018 in Bojonegoro Regency. At a temperature of 20-30 ${ }^{\circ} \mathrm{C}$ on the outskirts of Bojonegoro Regency, the average surface temperature of $30-35^{\circ} \mathrm{C}$ is found in almost all of Bojonegoro Regency, and a surface temperature of > $35^{\circ} \mathrm{C}$ is the highest in the Oil and Gas Mining and Mining Industrial Zone located in Gayam District, Bojonegoro Regency.

Keywords: surface temperature, oil and gas mining industry, GRDP, Bojonegoro

\begin{abstract}
Abstrak - Penelitian ini bertujuan untuk mengetahui perubahan suhu permukaan tanah industri Pertambangan dan Penggalian Migas. Metode yang digunakan yaitu analisi menggunakan Citra Land $5 \mathrm{Tm}$ tahun 1997 dan Citra Landsat 8 oli tahun 2018 dan melihat pertumbuhan PDRB Kabupaten Bojonegoro. Hasil dari penelitian ini sebagai berikut Suhu permukaan di Kabupaten Bojonegoro pada tahun 1997 ratarata $20-30^{\circ} \mathrm{C}$ dan $30-35^{\circ} \mathrm{C}$ berada di Kabupaten Bojonegoro bagian timur yaitu Sebagian Kecamatan Kanor, sebagian Kecamatan Baureno,sebagian Kecamatan Kepohbaru, sebagian Kecamatan Sumberejo, sebagian Kecamatan Kepohbaru dan sebagian Kecamatan Sokosewu. Namun terjadi kenaikan suhu permukaan tanah pada tahun 2018 di Kabupaten Bojonegoro. Pada suhu $20-30^{\circ} \mathrm{C}$ berada pada pinggiran Kabupaten Bojonegoro, suhu permukaan tanah $30-35^{\circ} \mathrm{C}$ rata-rata berada hampir di seluruh Kabupaten Bojonegoro, dan suhu permukaan tanah $>35^{\circ} \mathrm{C}$ paling tinggi pada Kawasan Industri Penggalian dan Pertambangan Migas yang berada di Kecamatan Gayam Kabupaten Bojonegoro.
\end{abstract}

Kata kunci: suhu permukaan, industri pertambangan migas, PDRB, Bojonegoro 


\section{PENDAHULUAN}

Di Indonesia dari tahun ke tahun tingkat pertumbuhan ekonomi mengalami peningkatan terutama pada sektor industri. Kawasan industri adalah suatu tempat pemusatan kegiatan industri yang dilengkapi dengan prasarana dan sarana yang disediakan dan dikelola oleh perusahaan industri, meningkatnya jumlah industri akan berdampak pada lingkungan sekitar yang mengakibatkan polusi lingkungan, keterbatasan infrastruktur dan masalah perkembangan kawasan permukiman yang berdekatan dengan industri. Kegiatan industri pertambangan migas merupakan kegiatan yang memiliki potensi yang besar dan mampu mendorong pertumbuhan ekonomi. Namun kegiatan industri pertambangan migas di Indonesia juga menimbulkan dampak negatif yaitu kerusakan lingkungan (Marta et al., 2014).

Iklim adalah salah satu faktor yang berpengaruh tidak hanya berdampak pada orang secara psikologis dan fisiologis tetapi juga mengendalikan perilaku hidup dan kegiatan ekonomi. Perubahan iklim disertai oleh urbanisasi, dimana manusia telah menciptakan habitatnya yang mana berkaitan erat dengan naiknya suhu permukaan. Meningkatnya suhu permukaan terjadi pada zona populasi yang sangat padat dan jarang adanya vegetasi, rata-rata terjadi pada daerah perkotaan (Ahmed, 2018). Peningkatan suhu permukaan juga diakibatkan adanya urbanisasi, hal tersebut rata-rata pada daerah perkotaan (Son et al., 2017). Sedangkan Effat et al., (2014) menjelaskan bahwa meningkatnya suhu permukaan akibat dari kebijakan manajemen yang lemah untuk area hijau. Menurut Yu et al., (2019) Perubahan suhu permukaan disebabkan adanya serangkaian penutupan lahan dan perubahan penggunaan lahan yang terkait dengan pengembangan sumberdaya mineral, khususnya Minyak dan Gas. Temuan dalam penelitian lainnya di Iran menunjukkan bahwa daerah yang dipengaruhi oleh naiknya suhu permukaan sering kali di bagian yang mana tutupan vegetasinya jarang, tanahnya gersang dan daerah kegiatan industri serta kawasan padat penduduk (Shirani-bidabadi et al., 2019).

Kabupaten Bojonegoro merupakan salah satu kabupaten di Provinsi Jawa Timur yang memiliki kontribusi PDRB cukup besar terhadap Provinsi Jawa Timur. Kabupaten Bojonegoro memiliki peran penting dalam menopang perekonomian Jawa Timur dan Perekonomian Nasional sendiri di topang oleh Provinsi Jawa Timur karena Bojonegoro sendiri memiliki kontribusi yang sangat tinggi pada sektor Pertambangan dan Penggalian, Berdasarkan data BPS, Produksi Industri Pertambangan dan Penggalian Migas sejak tahun 2007 hingga 2018 mengalami peningkatan. Dengan perkembangan Kabupaten Bojonegoro ini, maka perlu suatu penelitian untuk mengetahui perubahan suhu permukaan tanah dampak dari aktifitas industri penggalian dan pertambangan migas.

Penelitian ini bertujuan untuk mengetahui perubahan suhu permukaan tanah dengan menggunakan Citra Landsat tahun 1997 dan tahun 2018 di Kabupaten Bojonegoro akibat adanya Industri Pertambangan dan Penggalian Migas.

\section{METODE DAN DATA \\ Lokasi Penelitian}

Kabupaten Bojonegoro adalah salah satu Kabupaten di Provinsi Jawa Timur yang terletak pada $112^{\circ} 25^{\prime}-122^{\circ} 09^{\prime}$ Bujur Timur dan $6^{\circ} 59^{\prime}-7^{\circ} 37^{\prime}$ Lintang Selatan, secara administrasi Kabupaten Bojonegoro Terbagi menjadi 28 Kecamatan dan 430 desa/kelurahan. Berdasarkan posisi geografis, Kabupaten Bojonegoro memiliki batas wilayah: Utara : Kabupaten Tuban, Timur : Kabupaten Lamongan, Selatan: Kabupaten Madiun, Nganjuk dan Ngawi, dan Barat: Kabupaten Blora Propinsi Jawa Tengah. Berikut ini adalah peta administrasi Kabupaten Bojonegoro. 
Rendra, M. I \& Tamara,, A. P, 2020 Jurnal Sains Informasi Geografi [J SIG], 3(2):87-93, ISSN 2614-1671

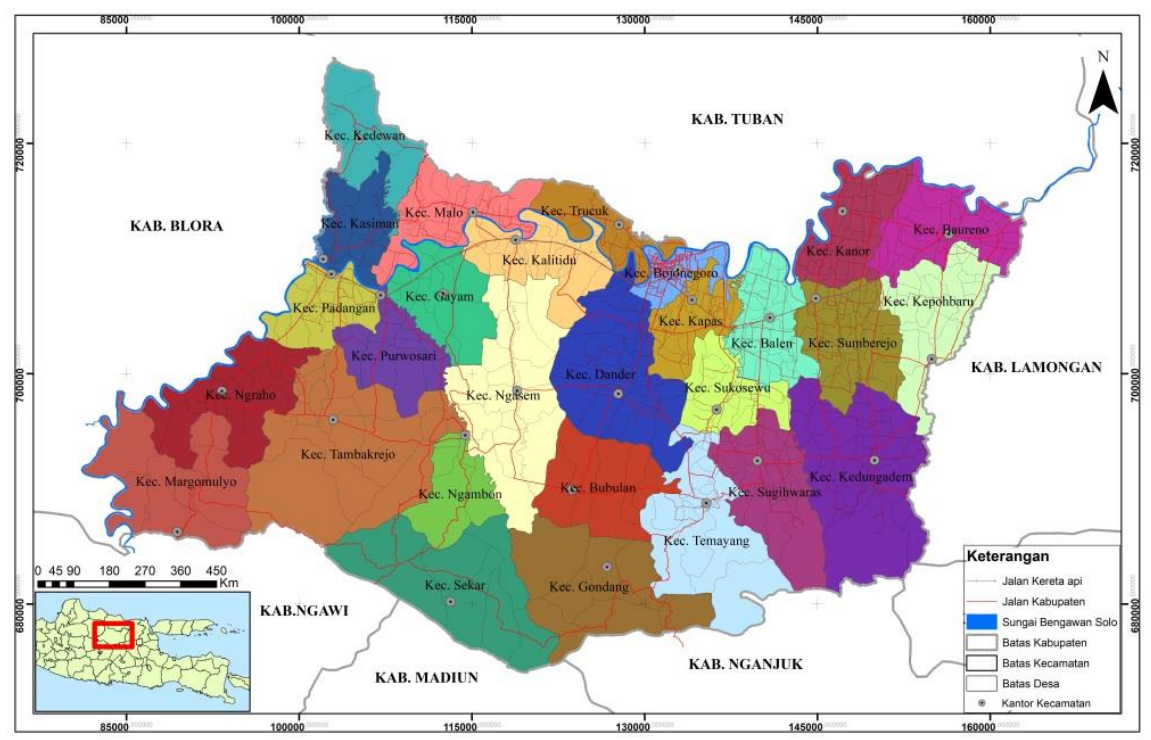

Gambar 1. Peta Administrasi Kabupaten Bojonegoro

\section{Produk Domestik Regional Bruto}

Produk Domestik Regional Bruto disamping merupakan salah satu indikator pembangunan daerah, juga sekaligus berfungsi sebagai tolak ukur dalam melihat kemakmuran suatu daerah. Dalam Produk Domestik Regional Bruto terdapat sektor- sektor ekonomi yang menyumbang besar kecilnya angka PDRB. Masing-masing sektor ekonomi tersebut memberikan sumbangan yang berlainan besarnya. Beberapa kegunaan serta analisis yang dapat diperoleh dari data PDRB antara lain besaran PDRB dapat digunakan untuk mengetahui potensi ekonomi suatu daerah dalam mengelola sumber daya alam dan sumber daya manusianya. Secara struktur ekonomi, PDRB dapat digunakan sebagai dasar analisis untuk mengetahui sektor-sektor ekonomi yang dominan di suatu daerah.

Tabel 1. PDRB Kabupaten Bojonegoro Tahun 2007-2018

\begin{tabular}{|c|c|c|c|c|c|c|c|c|c|c|c|c|}
\hline \multirow{2}{*}{$\begin{array}{c}\text { PDRB } \\
\text { Menurut } \\
\text { Lapanga } \\
\text { n Usaha }\end{array}$} & \multicolumn{12}{|c|}{ PDRB Atas Dasar Harga Berlaku (Milyar Rupiah) } \\
\hline & 2007 & 2008 & 2009 & 2010 & 2011 & 2012 & 2013 & 2014 & 2015 & 2016 & 2017 & 2018 \\
\hline Pertanian, & $\begin{array}{c}1828 . \\
1\end{array}$ & $\begin{array}{c}1898 . \\
5\end{array}$ & $\begin{array}{c}2032 . \\
7\end{array}$ & $\begin{array}{c}4848 . \\
8\end{array}$ & $\begin{array}{c}5020 . \\
2\end{array}$ & $\begin{array}{c}5290 . \\
4\end{array}$ & $\begin{array}{c}5495 . \\
2\end{array}$ & $\begin{array}{c}5610 . \\
4\end{array}$ & $\begin{array}{c}5792 . \\
6\end{array}$ & $\begin{array}{c}5959 . \\
9\end{array}$ & $\begin{array}{c}6023 . \\
8\end{array}$ & $\begin{array}{c}5963 . \\
7\end{array}$ \\
\hline $\begin{array}{l}\text { Pertambang } \\
\text { an dan } \\
\text { Penggalian }\end{array}$ & $\begin{array}{c}1800 . \\
7\end{array}$ & 2356 & $\begin{array}{c}2535 . \\
7\end{array}$ & $\begin{array}{c}16703 \\
.6\end{array}$ & $\begin{array}{c}19028 \\
.8\end{array}$ & $\begin{array}{c}19150 \\
.6\end{array}$ & $\begin{array}{c}18633 \\
.5\end{array}$ & $\begin{array}{c}18296 \\
.4\end{array}$ & $\begin{array}{c}24023 \\
.9\end{array}$ & $\begin{array}{c}33057 \\
.8\end{array}$ & $\begin{array}{c}37569 \\
.5\end{array}$ & $\begin{array}{c}38905 \\
.1\end{array}$ \\
\hline $\begin{array}{c}\text { Industri } \\
\text { Pengolahan }\end{array}$ & 290.6 & $\begin{array}{c}311.1 \\
2\end{array}$ & $\begin{array}{c}321.3 \\
9\end{array}$ & $\begin{array}{c}2004 . \\
3\end{array}$ & $\begin{array}{c}2129 . \\
7\end{array}$ & $\begin{array}{c}2240 . \\
8\end{array}$ & $\begin{array}{c}2351 . \\
4\end{array}$ & $\begin{array}{c}2501 . \\
1\end{array}$ & $\begin{array}{c}2630 . \\
3\end{array}$ & $\begin{array}{c}2762 . \\
0\end{array}$ & $\begin{array}{c}2972 . \\
2\end{array}$ & $\begin{array}{c}3176 . \\
6\end{array}$ \\
\hline $\begin{array}{c}\text { Pengadaan } \\
\text { Air, }\end{array}$ & 45.83 & 28.08 & 50.89 & 13.2 & 13.7 & 14.2 & 15.1 & 15.6 & 16.2 & 16.7 & 17.4 & 18.3 \\
\hline Konstruksi & $\begin{array}{c}210.3 \\
1\end{array}$ & $\begin{array}{c}225.6 \\
2\end{array}$ & $\begin{array}{c}244.3 \\
5\end{array}$ & $\begin{array}{c}2145 . \\
4\end{array}$ & $\begin{array}{c}2346 . \\
6\end{array}$ & $\begin{array}{c}2520 . \\
0\end{array}$ & $\begin{array}{c}2779 . \\
5\end{array}$ & $\begin{array}{c}3029 . \\
4\end{array}$ & $\begin{array}{c}3139 . \\
3\end{array}$ & $\begin{array}{c}3260 . \\
2\end{array}$ & $\begin{array}{c}3449 . \\
7\end{array}$ & $\begin{array}{c}3721 . \\
9\end{array}$ \\
\hline $\begin{array}{l}\text { Perdaganga } \\
\text { n Besar }\end{array}$ & $\begin{array}{c}1152 . \\
4\end{array}$ & $\begin{array}{c}1230 . \\
4\end{array}$ & $\begin{array}{c}1296 . \\
2\end{array}$ & $\begin{array}{c}2491 . \\
6\end{array}$ & $\begin{array}{c}2736 . \\
6\end{array}$ & $\begin{array}{c}3026 . \\
6\end{array}$ & $\begin{array}{c}3355 . \\
8\end{array}$ & $\begin{array}{c}3611 . \\
6\end{array}$ & $\begin{array}{c}3864 . \\
1\end{array}$ & $\begin{array}{c}4118 . \\
8\end{array}$ & $\begin{array}{c}4422 . \\
1\end{array}$ & $\begin{array}{c}4768 . \\
7\end{array}$ \\
\hline $\begin{array}{c}\text { Transportas } \\
\text { i dan } \\
\text { Pergudanga } \\
\text { n }\end{array}$ & $\begin{array}{c}257.7 \\
1\end{array}$ & $\begin{array}{c}268.1 \\
7\end{array}$ & $\begin{array}{c}286.9 \\
6\end{array}$ & 256.1 & 266.4 & 290.7 & 323.2 & 357.8 & 390.8 & 427.3 & 468.5 & 508.3 \\
\hline $\begin{array}{c}\text { Jasa } \\
\text { Keuangan } \\
\text { dan } \\
\text { Asuransi }\end{array}$ & $\begin{array}{c}283.7 \\
3\end{array}$ & $\begin{array}{c}312.6 \\
2\end{array}$ & $\begin{array}{c}329.9 \\
7\end{array}$ & 356.4 & 397.4 & 448.3 & 516.8 & 565.9 & 613.3 & 661.7 & 699.3 & 749.1 \\
\hline $\begin{array}{l}\text { Jasa-jasa/ } \\
\text { service }\end{array}$ & $\begin{array}{c}787.6 \\
8\end{array}$ & $\begin{array}{c}855.3 \\
6\end{array}$ & $\begin{array}{c}895.8 \\
5\end{array}$ & 305.0 & 322.8 & 333.2 & 351.1 & 370.1 & 387.3 & 404.6 & 419.6 & 444.7 \\
\hline
\end{tabular}

Sumber : BPS 2019 
Rendra, M. I \& Tamara,, A. P, 2020 Jurnal Sains Informasi Geografi [J SIG], 3(2):87-93, ISSN 2614-1671

\section{Data Citra Landsat}

Pengumpulan data citra sebagai raster yang digunakan penelitian menggunakan citra dari tahun 1997 (Landsat 5 TM) dan 2018 (Landsat 8 OLI), berbedaan 20 tahun untuk melihat perubahan suhu permukaan di Kabupaten Bojonegoro ,citra landsat dapat di akses pada laman https:/learthexplorer.usgs.gov, berikut tabel informasi citra landsat.

Tabel 2. Data Citra Landsat

\begin{tabular}{ccccccccc}
\hline No & Tahun & Tipe & Tanggal & Band & RMB & RAB & K1 & K2 \\
\hline 1 & 2018 & $\begin{array}{c}\text { Landsat } 8 \\
\text { OLI }\end{array}$ & $01-07-2018$ & 10 & 0.00033420 & 0.1 & 774.8853 & 1321.079 \\
2 & 1997 & $\begin{array}{c}\text { Landsat } 5 \\
\text { TM }\end{array}$ & $20-05-1997$ & 6 & 0.055375 & 1.18243 & 607.76 & 1260.56 \\
\hline
\end{tabular}

Metode Analisis

Land Surface Temperatur

Suhu Permukaan di definisikan sebagai suhu bagian dari suatu objek yang tidak sama tergantung fisik dan permukaan, pada sifat fisik permukaan objek yang berupa emisivitas, kapasitas massa panas dan konduktivitas termal. Menurut (Farras, et al., 2017; Nurgiantoro \& Aris, 2019; Sejati, et al., 2019; Sheng, et al., 2017; Shirani-bidabadi et al., 2019) suhu permukaan didapatkan dari perhitungan berikut, pertama dilakukan konversi dari DN piksel ke ToA Radiance menggunakan algoritma gain-offset.

$\mathbf{L} \lambda=\mathbf{M L} \mathbf{Q c a l}+\mathbf{A L}$

Keterangan:

$\mathrm{L} \lambda=$ TOA (Top of Atmosphere) spectral radiance (Watts/ (m2.srad. $\mu \mathrm{m})$ )

$\mathrm{ML}=$ Band-specific multiplicative rescaling factor

(RADIANCE_MULT_BAND_x, dimana x adalah band yang digunakan)

$\mathrm{AL} \quad=$ Band-specific additive rescaling factor

(RADIANCE_ADD_BAND_x,dimana x adalah band yang digunakan).

Qcal = nilai piksel $(\mathrm{DN})$. Mengubah nilai radiansi menjadi suhu kecerahan berikut :

Proses transformasi dari radiance ke temperature sensor, Menggunakan algoritma seperti

$$
\mathrm{Tk}=\frac{K 2}{\operatorname{Ln}\left(\frac{K 1}{L \lambda}+1\right)}
$$

Keterangan :

$\mathrm{Tk}=$ At-satellite brighness temperature $(\mathrm{K})$

$\mathrm{L} \lambda=$ TOA spectral radiance (Watts/ (m2.srad. $\mu \mathrm{m}))$

$\mathrm{K} 1=$ Band-specific thermal coversion constant

(K1_CONSTANT_BAND_x, dimana x adalah band yang digunakan)

$\mathrm{K} 2=$ Band-specific thermal coversion constant

(K2_CONSTANT_BAND_x, dimana $\mathrm{x}$ adalah band yang digunakan)

Temperatur sensor bukan suhu permukaan sehingga mendapatkan suhu permukaan dengan menggunakan persamaan seperti berikut :

$$
\text { Ts }=\mathbf{T}(\text { Kelvin })-273
$$

\section{HASIL DAN PEMBAHASAN}

Menurut Yu et al., (2019) Perubahan suhu permukaan disebabkan adanya serangkaian penutupan lahan dan perubahan penggunaan lahan yang terkait dengan pengembangan sumberdaya mineral, khususnya Minyak dan Gas. Meningkatnya suhu permukaan tanah juga diakibat adanya urbanisasi dan struktur permukaan kota (Son et al., 2017;Faria et al., 2018). Perubahan suhu permukaan dipengaruhi tutupan vegetasinya jarang dan daerah industri serta 

2614-1671

kawasan padat penduduk (Shirani-bidabadi et al., 2019). Perubahan tutupan lahan juga terjadi di Kabupaten Bojonegoro, salah satunya perubahan tutupan lahan pertanian menjadi Kawasan Industri Migas, Penelitian yang di lakukan oleh Rifa'i \& Mardiansjah, (2018) Kebutuhan lahan untuk mendukung aktivitas pertambangan minyak bumi seluas 700 ha, hal ini dapat dijadikan dugaan bahwa berkurangnya luasan tutupan lahan di Kabupaten Bojonegoro mempengaruhi kenaikan suhu permukaan sesuai dengan hasil kajian yang dilakukan (Yu et al., 2019).
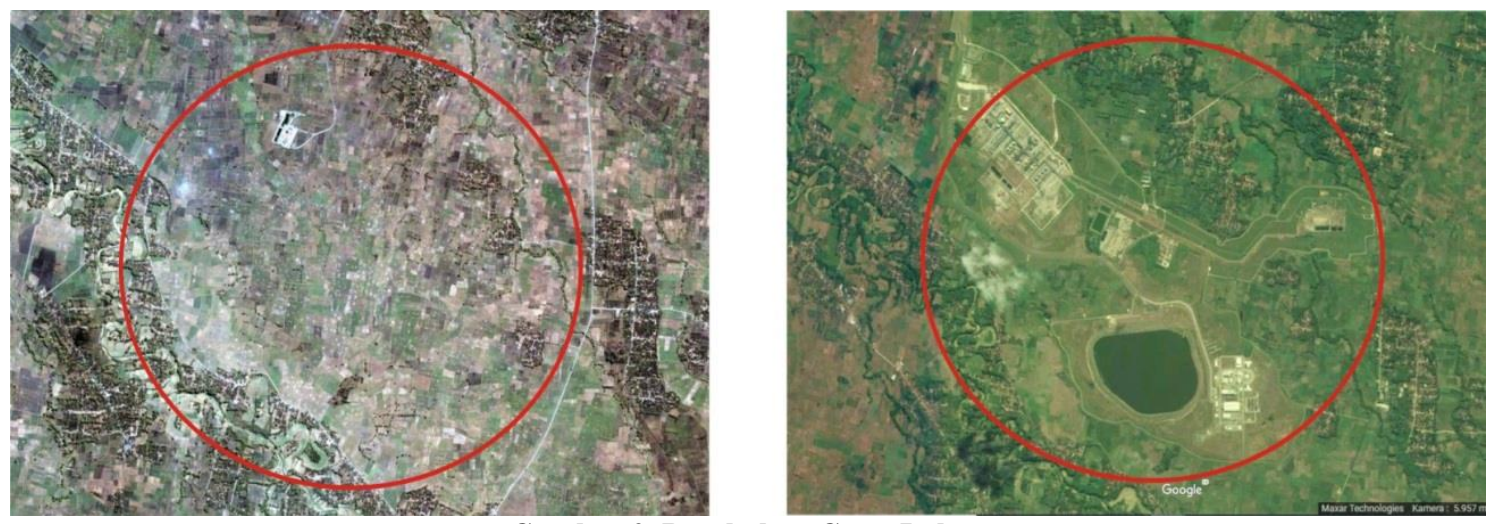

Gambar 2. Perubahan Guna Lahan

Sementara Hasil analisis Citra Landsat 8 OLI band 10 tahun 2018 suhu permukaan tanah di Kabupaten Bojonegoro pada suhu 20-30 ${ }^{\circ}$ berada pada pinggiran Kabupaten Bojonegoro, suhu permukaan tanah $\quad 30-35^{\circ} \mathrm{C}$ rata-rata berada hampir di seluruh Kabupaten Bojonegoro, dan suhu permukaan tanah $>35^{\circ} \mathrm{C}$ paling tinggi pada Kawasan Industri Penggalian dan Pertambangan Migas yang berada di Kecamatan Gayam Kabupaten Bojonegoro. Kenaikan suhu permukaan di Kabupaten Bojonegoro dapat dilihat pada tabel 3.

Tabel 3. Hasil Analisi Perubahan Suhu Permukaan Tanah Tahun 1997 dan 2018

\begin{tabular}{|c|c|c|}
\hline Temperatur & Landsat 5 TM tahun 1997 & Landsat 8 OLI tahun 2018 \\
\hline $20-30$ & Semua Kecamatan & 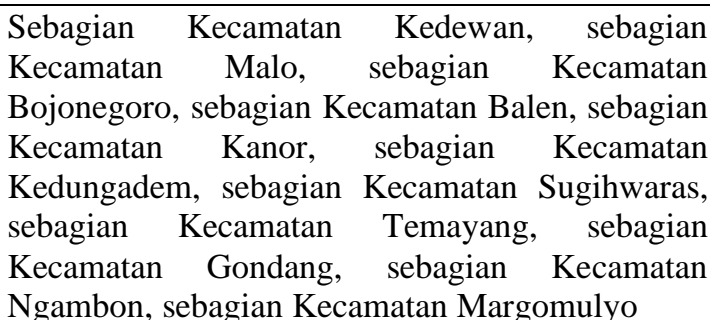 \\
\hline $30-35$ & 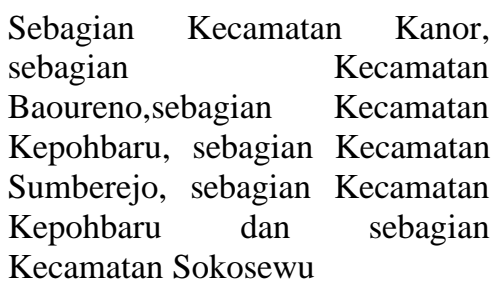 & Semua Kecamatan \\
\hline$>35$ & & 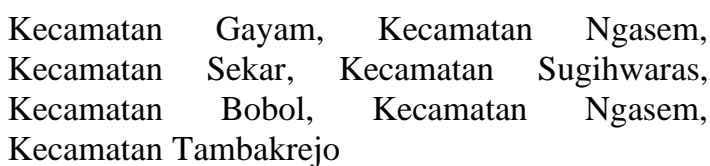 \\
\hline
\end{tabular}

Sumber : Analisis Penulis, 2019 

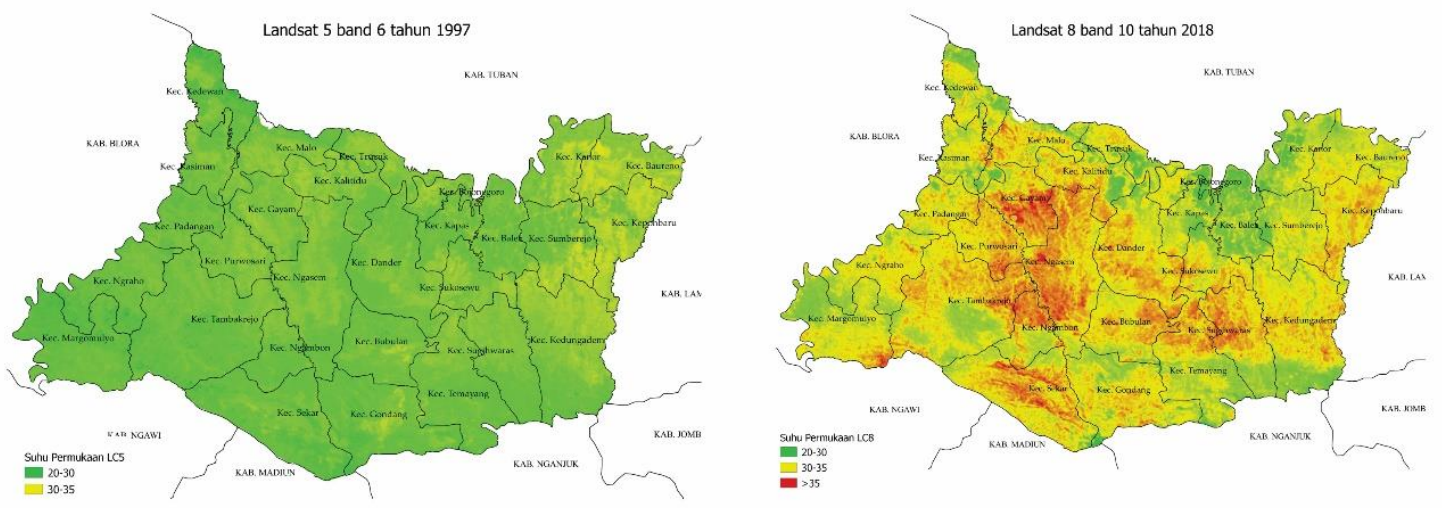

Gambar 3. Hasil Analisi Perubahan Suhu Permukaan Tanah

Kabupaten Bojonegoro merupakan kota migas yang memiliki cadangan minyak bumi dan gas dalam jumlah yang besar. Perkembangan sektor migas di Kabupaten Bojonegoro berkembang signifikan. Selama rentang tahun 2009 hingga 2018 terjadi peningkatan sebesar 36.369,4 milyar rupiah.

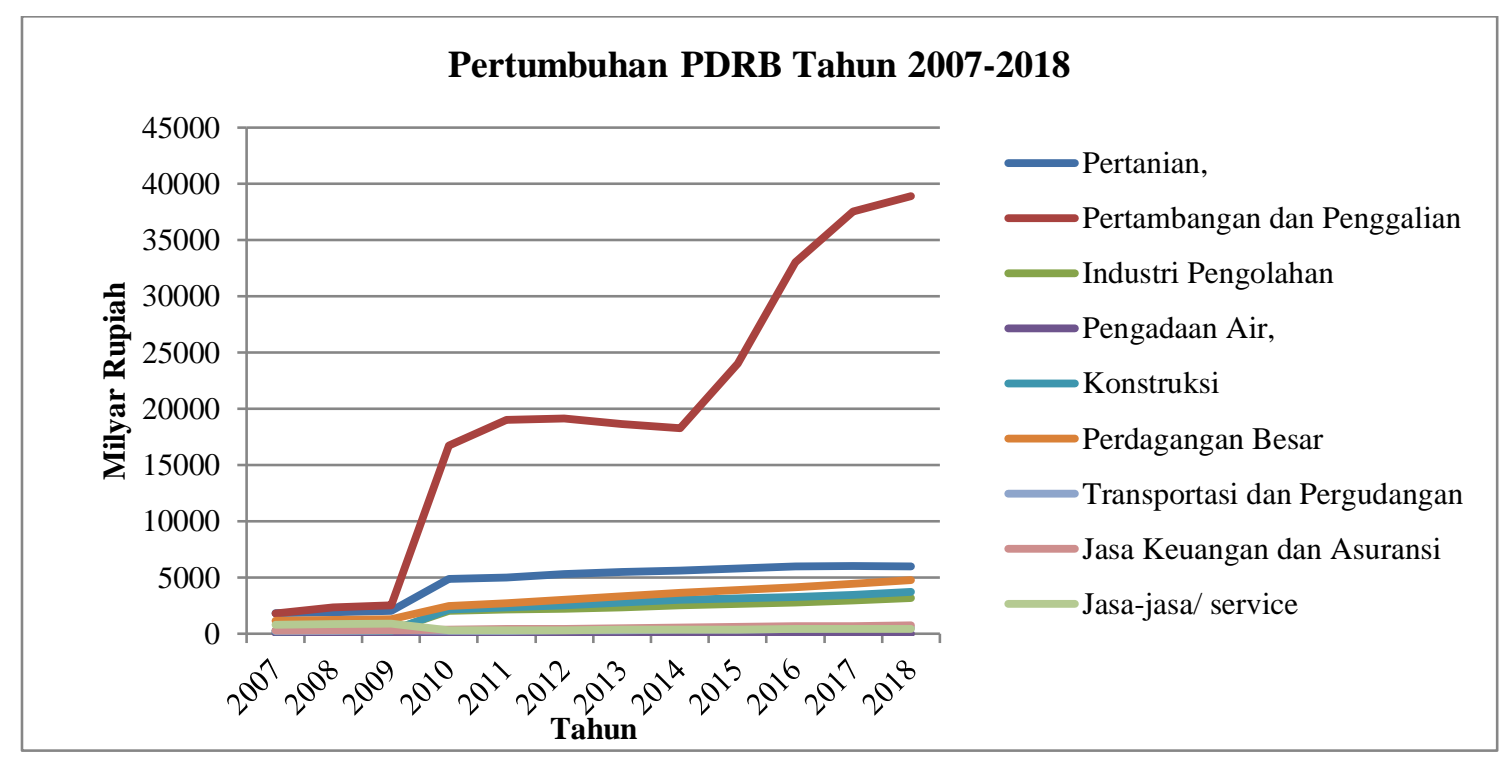

Gambar 4. Grafik Pertumbuhan PDRB Kabupaten Bojonegoro

Peningkatan aktivitas migas berdampak pada perubahan guna lahan pertanian menjadi lahan terbangun. Kajian yang dilakukan $\mathrm{Yu}$ et al., (2019) relevan dengan hasil penelitian ini bahwa terdapat korelasi antara peningkatan suhu permukaan tanah karena aktivitas migas, lahan terbangun yang terdapat di Kecamatan Gayam adalah sarana penunjang aktivitas migas. Tingginya aktivitas migas menyebabkan peningkatan kebutuhan ruang untuk penunjang aktivitas migas, maka terjadi alih fungsi lahan pertanian menjadi lahan terbangun.

\section{KESIMPULAN}

Suhu permukaan di Kabupaten Bojonegoro pada tahun 1997 rata-rata $20-30^{\circ} \mathrm{C}$ dan 30$35^{\circ} \mathrm{C}$ berada di Kabupaten Bojonegoro bagian timur yaitu Sebagian Kecamatan Kanor, sebagian Kecamatan Baoureno,sebagian Kecamatan Kepohbaru, sebagian Kecamatan Sumberejo, sebagian Kecamatan Kepohbaru dan sebagian Kecamatan Sokosewu. Namun terjadi kenaikan suhu permukaan tanah pada tahun 2018 di Kabupaten Bojonegoro. Pada suhu $20-30^{\circ} \mathrm{C}$ berada pada pinggiran Kabupaten Bojonegoro, suhu permukaan tanah $30-35^{\circ} \mathrm{C}$ rata-rata berada hampir di seluruh Kabupaten Bojonegoro, dan suhu permukaan tanah $>35^{\circ} \mathrm{C}$ paling tinggi pada Kawasan Industri Penggalian dan Pertambangan Migas yang berada di Kecamatan Gayam Kabupaten Bojonegoro. Berdasarkan data pertumbuhan PDRB Kabupaten Bojonegoro pada sektor migas mengalami peningkatan yang tinggi, selama rentang tahun 2009 hingga 2018 terjadi peningkatan sebesar 36.369,4 milyar rupiah. Tingginya aktivitas migas menyebabkan peningkatan kebutuhan 
Rendra, M. I \& Tamara,, A. P, 2020 Jurnal Sains Informasi Geografi [J SIG], 3(2):87-93, ISSN 2614-1671

ruang untuk penunjang aktivitas migas.

\section{DAFTAR PUSTAKA}

Ahmed, S. (2018). Assessment of urban heat islands and impact of climate change on socioeconomic over Suez Governorate using remote sensing and GIS techniques. The Egyptian Journal of Remote Sensing and Space Sciences, 21(1), 15-25. https://doi.org/10.1016/j.ejrs.2017.08.001

Badan Pusat Statistik Bojonegoro, 2019. Kabupaten Bojonegoro Dalam Angka Tahun 2019. Kabupaten Bojonegoro.

Badan Pusat Statistik Bojonegoro, 2009. Kabupaten Bojonegoro Dalam Angka Tahun 2009. Kabupaten Bojonegoro.

Effat, H. A., Abdel, O., \& Hassan, K. (2014). Change detection of urban heat islands and some related parameters using multi-temporal Landsat images ; a case study for Cairo city, Egypt. Urban Climate, 10, 171-188. https://doi.org/10.1016/j.uclim.2014.10.011

Faria, L. De, José, A., Lucena, D., Corrêa, O., Filho, R., Ricardo, J., \& França, D. A. (2018). The urban heat island in Rio de Janeiro , Brazil, in the last 30 years using remote sensing data. Int J Appl Earth Obs Geoinformation, 64(October 2016), 104-116. https://doi.org/10.1016/j.jag.2017.08.012

Farras, N., Sukmono, A., \& Bashit, N. (2017). Analisis Estimasi Energi Panas Bumi Menggunakan Citra Landsat 8 (Studi Kasus: Kawasan Gunung Telomoyo). 6.

Marta, A., Putri, S., Perencanaan, J., Teknik, F., Teknologi, I., Nopember, S., ... Indonesia, S. (2014). Menentukan Faktor yang Berpengaruh dalam Persebaran Pencemaran Industri Migas. 3(1), 2-5.

Nurgiantoro, \& Aris, A. (2019). Analisis Land Surface Emissivity menggunakan Data NDVI Landsat 8 dan Pengaruhnya terhadap Formasi Land Surface Temperature di Wilayah Kota Kendari. 01(02), 39-44.

Rifa'i, A. B., \& Mardiansjah, F. H. (2018). Agricultural Land Use Changes Impacts on the Farmers' Socio -. Tata Loka, 20(1), 50-64.

Sejati, A. W., Buchori, I., \& Rudiarto, I. (2019). The Spatio-Temporal Trends of Urban Growth and Surface Urban Heat Islands over Two Decades in the Semarang Metropolitan Region. Sustainable Cities and Society, 101432. https://doi.org/10.1016/j.scs.2019.101432

Sheng, L., Tang, X., You, H., Gu, Q., \& Hu, H. (2017). Comparison of the urban heat island intensity quantified by using air temperature and Landsat land surface temperature in $\begin{array}{lllll}\text { Hangzhou } \quad . & \text { Ecological } & \text { Indicators, }\end{array}$ https://doi.org/10.1016/j.ecolind.2016.09.009

Shirani-bidabadi, N., Nasrabadi, T., Faryadi, S., \& Larijani, A. (2019). Evaluating the spatial distribution and the intensity of urban heat island using remote sensing, case study of Isfahan city in Iran. Sustainable Cities and Society, 45(May 2018), 686-692. https://doi.org/10.1016/j.scs.2018.12.005

Son, N., Chen, C., Chen, C., \& Thanh, B. (2017). Assessment of urbanization and urban heat islands in Ho Chi Minh City, Vietnam using Landsat data. Sustainable Cities and Society, 30, 150-161. https://doi.org/10.1016/j.scs.2017.01.009

Yu, Q., Epstein, H. E., Engstrom, R., Shiklomanov, N., \& Strelestskiy, D. (2019). Land cover and land use changes in the oil and gas regions of Northwestern Siberia under changing climatic conditions Land cover and land use changes in the oil and gas regions of Northwestern Siberia under changing climatic conditions. 